\title{
An Astounding First Impact Factor for NRR
}

\author{
Emmanuel John M. Carranza ${ }^{1,2,3}$
}

In February 2017, our Natural Resources Research (NRR) journal was included in the Science Citation Index Expanded ${ }^{\mathrm{TM}}$ (also known as SciSearch ${ }^{\circledR}$ ), Journal Citation Reports ${ }^{\circledR}$ (JCR) Science Edition, and Current Contents ${ }^{\circledR} /$ Physical Chemical and Earth Sciences. In June 2018, NRR received its first Impact Factor (IF) — an astounding 3.094! This means that NRR now leads its sister journals-Mathematical Geosciences and Computers \& Geosciences-in terms of IF: 1.573 and 2.567, respectively. This is truly a remarkable milestone for NRR. This is a significant recognition of the high standard of our journal, and it characterizes the culmination of the development of our journal since it was founded in 1992 by Richard McCammon.

Our first IF was determined from citations to articles published in 2015 and 2016 . The top-10 most cited NRR articles published in 2015 and 2016 that contributed significantly to our first IF were all concerned with mineral resources (Table 1). This is not surprising because, traditionally, NRR is known for articles on the development of methods for

\footnotetext{
${ }^{1}$ School of Agricultural, Earth and Environmental Sciences, University of KwaZulu-Natal, Durban, Australia.

${ }^{2}$ Economic Geology Research Centre (EGRU), James Cook University, Townsville, QLD, Australia.

${ }^{3}$ To whom correspondence should be addressed; e-mail: ejmcarranza@gmail.com
}

mineral resource assessment (Carranza 2018) and for mineral potential mapping (Carranza 2017). As in 2015-2016, the major topic of articles published in NRR during 2016-2710 and 2017-2018 is mineral resources (Fig. 1). Therefore, we hope that our next IF (i.e., for 2016-2017 and 2017-2018, and beyond) will be maintained, if not improved.

The hope to maintain or improve our next IF for the next couple of years and beyond is based on two special issues on mineral resources, namely vol. 26(4) and vol. 27(2) published in 2017 and 2018, respectively. In addition, we are organizing for 2020 another special issue on mineral resources, namely about "Data Analysis Tools for Mineral Potential Mapping." However, we will publish this year 2019 a special issue on "Forests, Agriculture and Environmental Protection" and there are several forthcoming articles on groundwater resources. We are also planning special issues on other natural resources (water, geothermal, vegetation). Therefore, with the broadening of the topics of published NRR articles, we hope and aspire for the improvement of our IF in the years to come. 
Table 1. Top 10 most cited NRR articles, published in 2015 (volume 24) and 2016 (volume 25), which contributed significantly to NRR's first IF

\begin{tabular}{|c|c|c|c|c|c|}
\hline Article title & Author(s) & Volume & Issue & $\begin{array}{l}\text { Page } \\
\text { range }\end{array}$ & $\begin{array}{l}\text { Citations countec } \\
\text { for NRR's } \\
\text { first IF }\end{array}$ \\
\hline $\begin{array}{l}\text { Data-Driven Index Overlay and Boolean Logic } \\
\text { Mineral Prospectivity Modeling in Greenfields } \\
\text { Exploration }\end{array}$ & $\begin{array}{l}\text { Yousefi, M., Carranza, } \\
\text { E.J.M. }\end{array}$ & 25 & 1 & $3-18$ & 19 \\
\hline $\begin{array}{l}\text { A Comparative Analysis of Weights of Evidence, } \\
\text { Evidential Belief Functions, and Fuzzy Logic for } \\
\text { Mineral Potential Mapping Using Incomplete Data at } \\
\text { the Scale of Investigation }\end{array}$ & $\begin{array}{l}\text { Ford, A., Miller, JM., Mol, } \\
\text { A.G. }\end{array}$ & 25 & 1 & $19-33$ & 13 \\
\hline $\begin{array}{l}\text { Data-Driven Predictive Modeling of Mineral Prospectivity } \\
\text { Using Random Forests: A Case Study in Catanduanes } \\
\text { Island (Philippines) }\end{array}$ & $\begin{array}{l}\text { Carranza, E.J.M., Laborte, } \\
\text { A.G. }\end{array}$ & 25 & 1 & $35-50$ & 10 \\
\hline $\begin{array}{l}\text { Comparison of the Data-Driven Random Forests Model } \\
\text { and a Knowledge-Driven Method for Mineral } \\
\text { Prospectivity Mapping: A Case Study for Gold } \\
\text { Deposits Around the Huritz Group and Nueltin Suite, } \\
\text { Nunavut, Canada }\end{array}$ & McKay, G., Harris, J.R. & 25 & 2 & $125-143$ & 10 \\
\hline $\begin{array}{l}\text { Data-Driven Evidential Belief Modeling of Mineral } \\
\text { Potential Using Few Prospects and Evidence with } \\
\text { Missing Values }\end{array}$ & Carranza, E.J.M. & 24 & 3 & 291-304 & 9 \\
\hline $\begin{array}{l}\text { Application of Discriminant Analysis and Support Vector } \\
\text { Machine in Mapping Gold Potential Areas for Further } \\
\text { Drilling in the Sari-Gunay Gold Deposit, NW Iran }\end{array}$ & $\begin{array}{l}\text { Geranian, H. Tabatabaei, } \\
\text { S.H. Asadi, H.H., Car- } \\
\text { ranza, E.J.M. }\end{array}$ & 25 & 2 & $145-159$ & 8 \\
\hline $\begin{array}{l}\text { Spatial Modeling of Geometallurgical Properties: } \\
\text { Techniques and a Case Study }\end{array}$ & $\begin{array}{l}\text { Deutsch, J.L., Palmer, K., } \\
\text { Deutsch, C.V., Szyman- } \\
\text { ski, J., Etsell, T.H. }\end{array}$ & 25 & 2 & $161-181$ & 8 \\
\hline $\begin{array}{l}\text { Application of Global Particle Swarm Optimization for } \\
\text { Inversion of Residual Gravity Anomalies Over } \\
\text { Geological Bodies with Idealized Geometries }\end{array}$ & Singh, A., Biswas, A. & 25 & 3 & $297-314$ & 7 \\
\hline $\begin{array}{l}\text { An AHP-TOPSIS Predictive Model for District-Scale } \\
\text { Mapping of Porphyry Cu-Au Potential: A Case Study } \\
\text { from Salafchegan Area (Central Iran) }\end{array}$ & $\begin{array}{l}\text { Asadi, H.H., Sansoleimani, } \\
\text { A., Fatehi, M., Carranza, } \\
\text { E.J.M. }\end{array}$ & 25 & 4 & $417-429$ & 7 \\
\hline $\begin{array}{l}\text { Curvature Attribute from Surface-Restoration as } \\
\text { Predictor Variable in Kupferschiefer Copper } \\
\text { Potentials }\end{array}$ & $\begin{array}{l}\text { Mejia-Herrera, P., Royer, } \\
\text { J.J., Caumon, G., Cheil- } \\
\text { letz, A. }\end{array}$ & 24 & 3 & $275-290$ & 6 \\
\hline
\end{tabular}
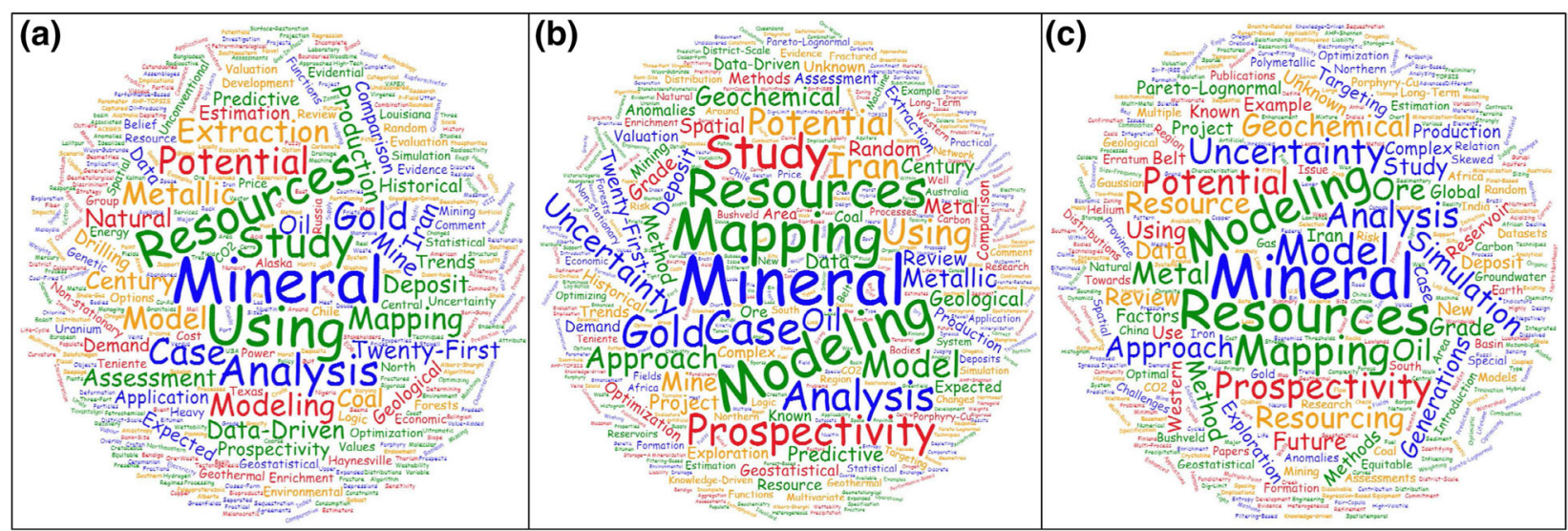

Figure 1. Clouds (or graphical histograms) of words from titles of NRR articles published during: (a) 2015-2016; (b) 2016-2017; and (c) 2017-2018. Word clouds were created using free online app (https://www.wordclouds.com/). 


\section{REFERENCES}

Carranza, E. J. M. (2017). Natural Resources Research publications on geochemical anomaly and mineral potential mapping, and introduction to the special issue of papers in these fields. Natural Resources Research, 26(4), 379-410.
Carranza, E. J. M. (2018). Natural Resources Research publications on resourcing future generations, and introduction of papers in this special issue. Natural Resources Research, $27(2), 125-141$. 